\title{
Penerapan Metode Mind Mapping dalam Upaya Meningkatkan Prestasi Belajar Pendidikan Kewarganegaraan Kompetensi Dasar Mendeskripsikan Pengertian dan Pentingnya Keterbukaan dan Keadilan dalam Kehidupan Berbangsa dan Bernegara bagi Siswa Kelas XI IPS 2 Sma Negeri 1 Blitar Pada Semester 1 Tahun Pelajaran 2010/2011
}

\author{
Eni Cahyowati ${ }^{(1)}$ \\ ${ }^{1}$ SMA NEGERI 2 BLITAR \\ Email: ${ }^{1}$ enicahyowati@gmail.com \\ DOI: https://doi.org/10.28926/riset_konseptual.v2i4.87
}

\begin{abstract}
ABSTRAK
Pendidikan di sekolah yang selama ini dilakukan diharapkan dapat mencerdaskan kehidupan bangsa dan mengembangkan manusia Indonesia seutuhnya, yaitu manusia yang beriman dan bertakwa terhadap Tuhan Yang Maha Esa dan berbudi pekerti luhur, memiliki pengetahuan dan keterampilian, kesehatan jasmani dan rohani, kepribadian yang mantap, mandiri serta rasa dan tindakan kelas dalam konteks pendidikan dengan mengkaji penerapan Metode Mind Mapping terhadap prestasi belajar Kewarganegaraan siswa SMA Negeri 1 Blitar dalam Kompetensi Dasar Mendeskripsikan Pengertian Dan Pentingnya Keterbukaan Dan Keadilan Dalam Kehidupan Berbangsa Dan Bernegara. Proses belajar berbeda dengan proses kematangan. Kematangan adalah proses sedemikian hingga tingkah laku dimodifikasi sebagai akibat dan pertumbuhan dalam perkembangan struktur serta fungsi-fungsi jasmani. Dengan demikian tidak setiap perubahan tingkah laku pada diri individu merupakan hasil belajar. Untuk menguji hipotesa tersebut akan dianalisa secara statistik dengan menggunakan SPSS, dengan menggunakan uji statistik non parametrik, uji bertingkat Wilcoxon. Dari hasil analisa diatas, terlihat bahwa pada kolom asymp.sig. (2-tailed) / asymptotic sinificance untuk uji 2 sisi adalah 0,000 , atau probabilitasnya dibawah $0,05(0,000 \mathrm{c} 0,005)$. Maka Ho ditolak, dan Ha diterima. Sehingga dapat disimpulkan bahwa peningkatan prestasi belajar Pendidikan Kewarganegaraan dengan Metode Mind Mapping akan lebih baik (meningkat) dibandingkan sebelumnya. Berdasarkan data dan analisisnya maka ada peningkatan yang bermakna dalam pretasi belajar mata pelajaran Pendidikan Kewarganegaraan pada Siklus II. Tabel output SPSS di atas juga menunjukkan bahwa nilai siswa yang tidak berubah (tetap) ada 3 orang, nilai siswa yang naik pada siklus 2 ada 1 orang, dan nilai yang sama pada kedua siklus ada 3 orang.
\end{abstract}

Kata kunci : mind mapping, prestasi belajar, pendidikan kewarganegaraan

\section{PENDAHULUAN}

Demi mewujudkan kualitas proses dan hasil belajar di sekolah maka perlu adanya inovasi dari seorang pendidik. Guru sangat berperan penting dalam hal tersebut. Salah satu cara yang dapat dilakukan untuk mewujudkan kualitas proses dan hasil belajar yaitu inovasi model pembelajaran dengan Mind Mapping. Model Mind Mapping dirasa mampu meningkatkan kemampuan pemahaman dan penerapan Pendidikan Kewarganegaraan siswa SMA guna meningkatkan kualitas proses dan hasil belajar Pendidikan Kewarganegaraan siswa SMA.

Selama ini, guru dalam pembelajaran Pendidikan Kewarganegaraan masih terlalu mekanistik dan strukturalistik, serta kurang memberikan keterkaitan antara materi pelajaran Pendidikan Kewarganegaraan dengan lingkungan kehidupan siswa, sehingga siswa kurang mampu menerapkan pengetahuan dan keterampilan Pendidikan Kewarganegaraan yang dimilikinya dengan kehidupan sehari-hari. 
Vol. 2 No. 4, Oktober 2018;

Penelitian ini ditujukan untuk mengetahui bagaimana perencanaan dan pelaksanaan pembelajaran Pendidikan Kewarganegaraan dengan pendekatan Mind Mapping dan kemampuan pemahaman dan penerapan Pendidikan Kewarganegaraan pada siswa SMA khususnya SMA Negeri 1 Blitar. Di samping itu pula untuk mengetahui pandangan guru terhadap pelatihan pembelajaran Pendidikan Kewarganegaraan dengan pendekatan Mind Mapping serta hambatan yang dihadapl guru dalam implementasi pembelajaran Pendidikan Kewarganegaraan dengan pendekatan Mind Mapping.

Peningkatan mutu pendidikan dapat dicapai melalui berbagal cara, antara lain melalui peningkatan kualifikasi pendidik dan tenaga kependidikan lainnya, pelatihan dan pendidikan, atau dengan memberikan kesempatan untuk menyelesaikan masalahmasalah pembelajaran dan non pembelajaran secara profesional lewat penelitian tindakan secara terkendall. Upaya meningkatkan kualitas pendidik dan tenaga kependidikan lainnya untuk menyelesaikan masalah-masalah yang dihadapi saat menjalankan tugasnya akan memberi dampak positif ganda. Pertama, kemampuan dalam menyelesaikan masalah pendidikan yang myata akan semakin meningkat. Kedua, penyelesaian masalah pendidikan dan pembelajaran melalui sebuah investigasi terkendali akan dapat meningkatkan kualitas isi, masukan, proses, dan hasil belajar. Dan ketiga, peningkatan kedua kemampuan tadi akan bermuara pada peningkatan profesionalisme pendidik dan tenaga kependidikan lainnya.

Pendidikan di sekolah yang selama ini dilakukan diharapkan dapat mencerdaskan kehidupan bangsa dan mengembangkan manusia Indonesia seutuhnya, yaitu manusia yang beriman dan bertakwa terhadap Tuhan Yang Maha Esa dan berbudi pekerti luhur, memiliki pengetahuan dan keterampilan, kesehatan jasmani dan rohani, kepribadian yang mantap, mandiri serta rasa tanggung jawab Kemasyarakatan dan Kebangsaan.

Di sekolah, keberhasilan mengajar guru tidak hanya ditentukan penguasaan pengetahuan guru tentang ilmu yang diajarkan tetapi ditentukan faktor-faktor antara lain: tujuan, metode dan cara menerapkan dalam proses belajar mengajar. Karena masing-masing metode mengajar mempunyai kelemahan dan kelebihan, maka untuk mencapai hasil yang memuaskan antara metode yang satu dengan metode yang lain perlu panduan mengajar yang tepat, sehingga diharapkan kelemahan metode mengajar yang satu akan tertutup oleh metode yang lain. Pendidikan harus dapat membantu siswa untuk mengembangkan bakat potensi, kreatifitas yang dimiliki siswa secara penuh menuju pembentukan manusia seutuhnya.

\section{METODE}

Pendekatan yang digunakan dalam penelitian ini adalah pendekatan kualitatif, dan kuantitatif. Penelitian ini berangkat dari masalah yang didapat di lapangan, kemudian direflesikan dan dianalisis berdasarkan teori yang menunjang, kemudian dilaksanakan tindakan-tindakan di lapangan. Kesimpulan yang diperoleh tidak dapat digeneralisasikan pada ruang lingkup yang lebih luas, karena untuk kondisi dan situasi yang berbeda hasilnya dapat berbeda. Penelitian ini dapat dijadikan model untuk memberikan rekomendasi pada situasi yang lain. Adapun tujuan penelitian untuk mengetahui perbedaan perolehan hasil belajar Pendidikan Kewarganegaraan antara pembelajaran dengan metode Mind Mapping dengan pembelajaran konvensional dan untuk mengetahui efektifitas pembelajaran terpadu di SMA. Sedangkan manfaat penelitian ini untuk melatih dan mengembangkan cara berpikir kritis dengan mengaitkan hal yang ada di lingkungan siswa, bagi guru hasil penelitian ini dapat meningkatkan teknik penyampaian proses belajar mengajar sehingga dapat mengembangkan proses berfikir siswa dan bagi para praktisi pendidikan memberi masukan bahwa pembelajaran Pendidikan Kewarganegaraan lebih efektif diberikan pada anak dengan pembelajaran metode Mind Mapping. 


\section{Rancangan Penelitian}

Penelitian ini menggunakan rancangan Penelitian Tindakan Kelas (clarssroom action research). Penelitian terdiri dari 2 siklus, masing-masing siklus mempunyaii 4 tahap, yaitu menyusun rencana tindakan, melaksanakan tindakan, melakukan observasi, melakukan refleksi. Setelah dilakukan refleksi yang mencakup analisis, sintesis, dan penilaian terhadap proses serta hasil tindakan akan timbul perencanaan baru untuk siklus berikutnya. Sebelum memasuki siklus I peneliti mengidentifikasi masalah terlebih dahulu. Berapa masalah yang beridentifikasi diantaranya yaitu metode pembelajaran, rencana pembelajaran dan lembar kerja siswa (IRP dan LKS), serta beberapa informasi tentang karakter siswa secara klasikal.

\section{Objek Penelitian}

Penelitian ini melibatkan seluruh siswa Kelas XI 1PS 2 di SMA Negeri 1 Bitar tahun ajaran 2010/2011.

\section{Tempat dan Waktu Penelitian}

Penelitian dilaksanakan di SMA Negeri 1 Bitar pada Semester 1, tahun ajaran 2010/2011.

\section{Prosedur Pengumpulan Data}

Data yang digunakan pada penelitian adalah hasil belajar siswa yang dilakukan melalui tes. Tes ini untuk mengungkap perolehan hasil belajar siswa dalam mengikuti pembelajaran, baik tes awal yaitu tes yang dilakukan sebelum diberikan perlakuan maupun tes akhir yaitu tes yang diberikan setelah perlakuan. Sedangkan teknik non tes digunakan untuk mengungkap sikap, motivasi, dan minat anak yang merupakan dampak pengiring darl proses pembelajaran Penelitian ini merupakan penelitian tindakan karena dari analisis dan refleksi setiap akhir kegiatan dilakukan tindakan yang berdasarkan pada hasil analisis dan refleksi yang dibuat sebelumnya.

\section{Analisis Data}

Data hasil observasi pembelajaran dianalisis bersama-sama, kemudian ditafsirkan berdasarkan kajan pustaka dan pengalaman guru. Hasil belajar siswa dianalisis berdasarkan ketuntasan belajar siswa, yaitu $80 \%$ siswa sudah mencapai $65 \%$ taraf pengusaan konsep-konsep yang diberikan

\section{HASIL}

Berdasarkan data yang telah dikumpulkan didapat nilai rata-rata kelas antara Siklus I dan Siklus II berbeda. Nilai rata-rata kelas Siklus I adalah sebesar 65.11, sedangkan nilai rata-rata kelas Siklus II adalah sebesar 77.6 Sehingga selisih kenaikan rata-rata kelas adalah 12.49. Dari perbedaan di atas dapat dilihat bahwa perlakuan metode Mind Mapping pada pembelajaran Pendidikan Kewarganegaraan akan dapat meningkatkan nilai siswa.

Untuk menguji hipotesa tersebut akan dianalisa secara statistik dengan menggunakan SPSS, dengan menggunakan uji statistik non parametrik, uji bertingkat Wilcoxon. Berdasarkan hasil analisa terlihat bahwa pada nilai asymp.sig. (2tailed)/asymptotic sinificance untuk uji 2 sisi adalah 0,000 , atau probabilitasnya dibawah $0,05(0,000 \mathrm{c} 0,005)$. Maka Ho ditolak, dan Ha diterima. Sehingga dapat disimpulkan bahwa peningkatan prestasi belajar Pendidikan Kewarganegaraan dengan Metode Mind Mopping akan lebih baik (meningkat) dibandingkan sebelumnya. Berdasarkan data dan analisisnya maka ada peningkatan yang bermakna dalam pretasi belajar mata pelajaran Pendidikan Kewarganegaraan pada Siklus il. Tabel output SPSS di atas juga menunjukkan bahwa nilai siswa yang tidak berubah (tetap) ada 3 orang, nilai siswa yang naik pada siklus 2 ada 15 orang, dan nilai yang sama pada kedua siklus ada 3 orang. 


\section{PEMBAHASAN}

Siklus I berlangsung 2 kali pertemuan ( 4 x 40 menit). Gambaran umum tentang proses pembelajaran dan situasi kelas selama pembelajaran dan situasi kelas selama pembelajaran yaitu Kompetensi Dasar yang diberikan memuat aspek pengetahuan, secara terintegrasi dengan mengembangkan bahan-bahan yang aktual. Sedangkan proses pembelajarannya cenderung diwarnai oleh orientasi pada pencapaian target kurikulum. Adanya keseimbangan dalam pembelajaran, dimana proses hafalan diberi porsi yang sama dengan pengembangan berfikir dan pengembangan nilai, ditambahkan lagi evaluasi yang lebih menekankan aspek kognitf. Pembelajaran terpola pada interaksi yang timbal balik antara siswa dan guru.

Ada beberapa kegiatan pokok yang dilakukan dalam pelaksanaan pembelajaran ini. Pertama, mempersiapkan kelas untuk menerima pembelajaran. Kedua, kegiatan inti pembelajaran seperti membimbing siswa dalam mengamati gambar agar keadaan kelas tetap aman dan tertib, memperhatikan cara kerja siswa dalam kelompoknya, mengawasi siswa dalam pembuatan laporan, mendiskusikan temuan- temuan yang didapat siswa, dan bersama-sama siswa mengumpulkan gambar-gambar serta mengatur kelas.

Siklus kedua berlangsung dua kali tatap muka ( 4 x 40 menit). Tindakan yang diberikan pada siswa adalah siswa diberikan tugas mendiskusikan beberapa topik tentang pers. Gambaran umum tentang proses pembelajaran dan situasi kelas selama pembelajaran berlangsungnya adalah sebagai berikut: (1) Melalui diskusi kelompok (kerja kelompok) siswa diminta mengerjakan LKS. (2) Suasana kelas sangat kondusif, siswa dengan serius berdiskusi dalam kelompoknya masing-masing namun suasana kelas tidak gaduh. Masing-masing anegota kelompok aktif dan berani untuk mengemukakan pendapat. (3) Koordinasi antar anggota kelompok cukup bagus. Mereka bertanggung jawab terhadap tugas yang diberikan. Pada umumnya mereka bisa menyimpukan apakah arti keterbukaan dan keadilan dalam.kehidupan berbangsa dan bernegara. (4) Setelah semua kelompok menempelkan posternya di papan tulis dilanjutkan diskusi kelas. Pada waktu guru menanyakan kelompok berapa yang akan menjelaskan posternya, wakil-wakil kelompok sudah berani mengacukan tangan. Ini merupakan kemajuan dibanding pada siklus I. (5) Diskusi kelas cukup lancar, kelompok penyaji yaitu kelompok 1 menjelaskan posternya cukup lantar dan kelompok yang lain aktif menanganinya. Hal ini terlibat dari jumlah siswa yang mengangkat tangan sebanyak 15 siswa (34.09). Dengan demikian, berarti pada waktu siswa berdiskusi dalam kelompok (mengerjakan LKS) sudah memikirkan permasalahan yang dihadapi. (6) Selanjutmya siswa diminta untuk mendiskusikan hubungan Konstitusi Negara dengan demokratisasi Mereka sangat antuslas dan aktif diskusi dalam kelompok sehingga suasana kelas cukup ramai. Masing-masing kelompok menuliskan hasil diskusi pada format yang telah disediakan peneliti dan kemudian dkumpulkan.

\section{KESIMPULAN}

Hasil penelitian terhadap 21 siswa Kelas XI IPS 2 SMA Negeri 1 Blitar, Kota Blitar menunjukkan bahwa pemberian Metode Mind Mapping dapat meningkatkan prestasi belajar siswa pada mata pelajaran Pendidikan Kewarganegaraan Kompetensi Dasar Mendeskripsikan Pengertian Dan Pentingnya Keterbukaan Dan Keadilan Dalam Kehidupan Berbangsa Dan Bernegara. Berdasarkan data dan analisisnya maka ada peningkatan yang bermakna dalam pretasi belajar mata pelajaran Pendidikan Kewarganegaraan pada Siklus 2 jika mendapat Metode Mind Mapping. Hal ini ditunjukkan dari nilai rata-rata kelas siklus I sebesar 65.11 menjadi 77.6 pada siklus II. Kesimpulan tersebut menunjukkan bahwa prestasi belajar siswa dipengaruhi oleh faktor eksternal, dalam hal ini sikap guru yang memberikan Metode Mind Mapping kepada siswa. 


\section{SARAN}

Dalam penelitian ini ada beberapa saran antara lain: Penelitian ini sebaiknya dilakukan terhadap beberapa kelas secara bergantian, sehingga dapat diketahui dengan apakah Metode Mind Mopping dapat meningkatkan pemahaman siswa terhadap materi pelajaran lebih menyeluruh. Mengingat banyaknya metode pembelajaran yang dapat dilakukan oleh guru, maka pemakaian metode pembelajaran yang bervariasi akan membuat situasi kelas lebih menarik bagi siswa.

\section{DAFTAR RUJUKAN}

Arifin, Zainal. 1989. Evaluasi Instruksional. Jakarta: Gramedia.

Arikunto. 1988. Dasar-Dasar Evaluasi Pendidikan. Bina Aksara.

Nasution, S. 1987. Berbagai Pendekatan dalam Proses Belajar Mengajar. Bina Aksara.

Nasution, S. 1987. Berbagai Pendekatan dalam Proses Belajar Mengajar. Bina Aksara.

Slameto. 1988. Belajar dan Faktor-faktor yang Mempengaruhinya. Jakarta: Bina Aksara.

Soemanto, Wasty. 1990. Psikologi Pendidikan: Landasan Kerja Pemimpin Pendidikan (Cetakan Ke 5). Jakarta: Rineka Cipta. 